\title{
Renal Effects of Atrial Natriuretic Peptide Infusion in Young and Adult Rats ${ }^{1}$
}

\author{
ROBERT L. CHEVALIER, R. ARIEL GOMEZ, ROBERT M. CAREY, MICHAEL J. PEACH, AND \\ JOEL M. LINDEN \\ WITH THE TECHNICAL ASSISTANCE OF CATHERINE E. JONES, NANCY V. RAGSDALE, AND BARBARA THORNHILL
}

Departments of Pediatrics [R.L.C., A.R.G., C.E.J., B.T.], Internal Medicine [R.M.C., J.M.L., N.V.R.], Pharmacology [M.J.P.], and Physiology [J.M.L.], University of Virginia, School of Medicine, Charlottesville, Virginia 22908

\begin{abstract}
The immature kidney appears to be less responsive to atrial natriuretic peptide (ANP) than the mature kidney. It has been proposed that this difference accounts for the limited ability of the young animal to excrete a sodium load. To delineate the effects of age on the renal response to exogenous ANP, Sprague-Dawley rats were anesthetized for study at 31-32 days of age, 3541 days of age, and adulthood. Synthetic rat ANP was infused intravenously for $\mathbf{2 0} \mathrm{min}$ at increasing doses ranging from 0.1 to $0.8 \mu \mathrm{g} / \mathrm{kg} / \mathrm{min}$, and mean arterial pressure, glomerular filtration rate, plasma ANP concentration, urine flow rate, and urine sodium excretion were measured at each dose. Since cyclic GMP acts as a second messenger for ANP action, urinary cyclic GMP excretion also was measured. Increasing doses of ANP caused a similar decrease in MAP at all ages studied, and increased glomerular filtration rate in adult but not young rats. Increasing the dose of ANP from 0.1 to $0.4 \mu \mathrm{g} / \mathrm{kg} / \mathrm{min}$ caused a greater rise in urine flow and urinary cyclic GMP excretion in adult than young rats, and urine sodium excretion increased more in adults at all doses $(p<0.05)$. However, the rise in plasma ANP concentration also was greater in adults than in young rats $(p<0.05)$, indicative of greater systemic clearance of ANP in young animals. Increasing levels of plasma ANP concentration were correlated with a greater rise in urine flow in adult than young (31-32 day old) rats $(p<0.05)$, but there was no differential effect on urinary cyclic GMP excretion. We conclude that although the diuretic effect of ANP increases with age, the guanylate cyclase response to ANP does not change after $\mathbf{3 0}$ days of age in the rat. Decreasing clearance of ANP as rats age may be due to decreased enzymatic degradation of the peptide or reduced removal as a result of altered receptor binding. (Pediatr Res 24: 333-337, 1988)
\end{abstract}

\section{Abbreviations}

ANP, atrial natriuretic peptide

Received February 2, 1988; accepted May 10, 1988

Correspondence and reprint requests Robert L. Chevalier, M.D., Department of Pediatrics, Box 386, University of Virginia, School of Medicine, Charlottesville, VA 22908.

Supported by National Institutes of Health Biomedical Research Support Award 5 S07 RR05431-25 and NIH Grant 1 R01 HL40209-01. Data handling and analysis was made possible in part by NIH Grant M01 RR00847 to the University of Virginia General Clinical Research Center. This work was done during the tenure of Established Investigator Awards of the American Heart Association (R.L.C., J.L.).

1 The results of this study were presented in part at the 20th Annual Meeting of the American Society of Nephrology, Washington DC, December 1987 and the Annual Meeting of the Society for Pediatric Research, Washington DC, May 1988, and published in abstract form (Kidney Int 33:258, 1988; Pediatr Res 23:533A, 1988)
GFR, glomerular filtration rate

MAP, mean arterial pressure

$\mathrm{U}_{\mathrm{CGMP}} \mathrm{V}$, urinary cGMP excretion

$\mathrm{U}_{\mathrm{Na}} \mathrm{V}$, urinary sodium excretion

By comparison to the adult kidney, the immature kidney responds to volume expansion with a more limited diuresis and natriuresis (1). A number of factors have been implicated to explain this phenomenon in the neonatal kidney, including a smaller increase in GFR, redistribution of renal blood flow, and increased distal tubular reabsorption (1). It presently appears that enhanced distal reabsorption is primarily responsible for the limited response of the immature kidney $(2,3)$. Despite morphologic renal maturation by the end of the first month of life in the rat, renal functions mature in discrete critical time periods even after the neonatal period. Hence, a prompt diuresis and natriuresis after acute blood volume expansion does not develop until 30 to 40 days of age (4). These observations may be due to a circulating factor present in the adult but deficient in the young animal (5).

Since its discovery in 1981 (6), ANP has been intensively investigated, and the peptide is now thought to play an important role in volume homeostasis (7). If ANP contributes to the maturational increase in the efficiency of diuresis and natriuresis in response to acute volume expansion, several possibilities exist. First, release of the active peptide from cardiac tissue may increase during development; second, the renal response to circulating ANP may increase with growth; and third, molecular processing or metabolism of the peptide may change such that ANP clearance decreases with age.

The present study was designed to compare the renal response to graded infusion of ANP in young and adult rats. Plasma ANP was measured at each infusion rate so that functional renal response could be related to circulating levels of the peptide. Inasmuch as cGMP is known to act as a second messenger for ANP action (8), $U_{\text {CGMP }} V$ also was measured.

\section{MATERIALS AND METHODS}

Experiments were performed using three groups of SpragueDawley rats: adult rats weighing 212 to $301 \mathrm{~g}(n=6)$, rats

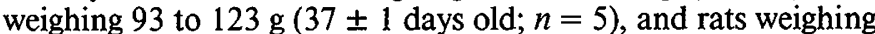
68 to $92 \mathrm{~g}(31.5 \pm 0.2$ days old; $n=5)$. The age groups of young rats were selected because a marked increase in diuretic and natriuretic response to acute blood volume expansion normally develops from 30 to 40 days of age (4). Animals were anesthetized with intraperitoneal sodium pentobarbital (Abbott Laboratories, North Chicago, IL), $50 \mathrm{mg} / \mathrm{kg}$, and placed on a thermostatically controlled heating table. After tracheotomy, a carotid artery was 
cannulated for blood sampling and monitoring of MAP with a Statham 23ID transducer connected to a recorder (HewlettPackard 2544, Hewlett-Packard Co., Palo Alto, CA). A jugular vein was cannulated for infusion of $A N P$, and the contralateral jugular vein was cannulated for continuous infusion of $0.85 \%$ saline at $0.3 \mathrm{ml} / \mathrm{kg} / \mathrm{min}$. This catheter was also used for replacement of blood withdrawn for samples with whole blood obtained from anesthetized untreated adult donor rats. The proximal left ureter was exposed through an abdominal incision and cannulated for urine collection in preweighed cups.

After a 1-h equilibration period, a 20 -min urine collection was obtained, at the end of which a 2-ml blood sample (adults) or 1$\mathrm{ml}$ sample (young rats) was withdrawn from the arterial catheter over a 3-min period. Donor rat blood simultaneously was infused at the same rate as withdrawal to maintain a constant blood volume. Hematocrit was measured in micro-hematocrit tubes, and the remainder of the blood sample, collected in EDTA, was centrifuged at $4^{\circ} \mathrm{C}$ for $10 \mathrm{~min}$. Plasma and urine samples were stored at $-70^{\circ} \mathrm{C}$ before assays for ANP and cGMP.

Immediately after the initial collection of urine and blood, synthetic rat ANP (28 amino acid peptide, Peninsula Laboratories, Belmont, CA) $5 \mu \mathrm{g} / \mathrm{ml}$ in $5 \%$ dextrose in water, was infused intravenously at a rate of $0.1 \mu \mathrm{g} / \mathrm{kg} / \mathrm{min}(0.02 \mathrm{ml} / \mathrm{kg} / \mathrm{min})$ during a second 20 -min urine collection period. The rate of ANP infusion then was increased by changing the rate of infusion to $0.2,0.4$, and $0.8 \mu \mathrm{g} / \mathrm{kg} / \mathrm{min}$ at the beginning of subsequent 20 min collection periods in all animals, and to $1.6 \mu \mathrm{g} / \mathrm{kg} / \mathrm{min}$ in five of the young rats. A blood sample was obtained at the end of each collection period and was replaced with an equal volume of donor blood as described above.

Because inulin clearance could not be measured in animals undergoing repeated blood withdrawal and replacement for ANP determinations, GFR was measured by inulin clearance in separate groups of adult rats (195 to $257 \mathrm{~g}$ body weight; $n=5$ ) and young rats ( 34 to 37 days old; $n=5$ ). Animals were anesthetized and surgically prepared as described above. Saline containing $\left[{ }^{3} \mathrm{H}\right]$ inulin (New England Nuclear, Boston, MA) in a concentration of $10 \mu \mathrm{Ci} / \mathrm{ml}$ was infused throughout the experiment at 0.3 $\mathrm{ml} / \mathrm{kg} / \mathrm{min}$. After a $1-\mathrm{h}$ equilibration period, a 20-min urine collection was obtained, followed by ANP infusion in four sequential 20-min increments of 0.1 to $0.8 \mu \mathrm{g} / \mathrm{kg} / \mathrm{min}$ as described above. Blood samples $(0.1 \mathrm{ml})$ were obtained between each urine collection period. Radioactivity of plasma and urine aliquots was measured in a $\beta$-scintillation counter (Beckman Instruments, Irvine, $\mathrm{CA}$ ) and inulin clearance was calculated as the product of urine flow and urine to plasma activity ratio. At the end of the experiment, the animal was killed by intravenous infusion of saturated potassium chloride solution, and the kidneys were excised, drained, and weighed.

Assays. ANP. Plasma ANP was measured by radioimmunoassay. Plasma samples were acidified $(1: 1)$ with $0.6 \%$ trifluoroacetic acid, extracted over octyldecylsilane cartridges (Sep-Pac, Waters Associates, Milford, MA), evaporated to dryness (Speed Vac, Savant Instruments, Farmingdale, NY), and reconstituted in $0.05 \mathrm{M}$ phosphate buffer containing $2.0 \mathrm{mg} / \mathrm{ml}$ bovine serum albumin ( $\mathrm{pH} 7.4$ ). Samples were incubated for $72 \mathrm{~h}$ at $4^{\circ} \mathrm{C}$ with rabbit anti-rat ANP (Peninsula Laboratories, Belmont, CA) and monoradioiodinated rat ANP (New England Nuclear). Serially diluted rat ANP (Peninsula Laboratories) was used for assay standards. Free tracer was separated from bound by the addition of $0.05 \%$ dextran- $0.5 \%$ charcoal $(1: 1)$ with sample, followed by rapid mixing, equilibration for $5 \mathrm{~min}$, and centrifugation at $4^{\circ} \mathrm{C}, 5,000 \mathrm{rpm}$ for $20 \mathrm{~min}$. The samples were decanted and the amount of radioactivity present in the supernatants was determined (Gamma 300, Beckman Instruments, Columbia, MD). Data were analyzed by a computerized logit-log transformation program on an AT\&T microcomputer. Efficiency of extraction of ANP by this method was 93-97\%; and recovery of unlabeled ANP through the entire procedure was $87 \%$. The lowest detectable ANP concentration was $3.3 \mathrm{pg} / \mathrm{sample}$; intraassay variation was $4.6 \%$; and interassay variation was $9.7 \%$.

Sodium. Urine sodium concentration was measured by flame photometer (Corning model 435, Corning Glass Works, Medfield, MA), with lithium as the internal standard.

Urine cGMP. Urine cGMP concentration was measured by automated radioimmunoassay (9). The radioligand, ${ }^{125} \mathrm{I}-2^{\prime}-0$ succinyl-cyclic nucleotide tyrosine methyl ester, was prepared as described (10).

Statistical analysis. Dose-response curves were analyzed by linear regression using the method of least squares, and slopes and intercepts were compared between groups using analysis of variance (SAS Institute, Cary, NC). Inasmuch as the relationship was linear only for infusion rates of ANP up to $0.4 \mu \mathrm{g} / \mathrm{kg} / \mathrm{min}$, comparisons were made for rates of 0.0 to $0.4 \mu \mathrm{g} / \mathrm{kg} / \mathrm{min}$. To account for differences between groups in plasma concentration of ANP at each infusion rate, data also were analyzed as a function of plasma ANP concentration. Because there were no differences between 31- to 32-day-old and 35- to 41-day-old groups in the relationship of measured parameters to ANP infusion dose, for the sake of clarity only the youngest group was compared to the adult group in the correlations with plasma ANP concentration. Changes in GFR resulting from incremental ANP infusion were assessed by single-factor repeated measures analysis of variance. Differences were considered to be statistically significant at $p<0.05$.

\section{RESULTS}

As shown in Table 1, kidney weight increased with age of the rats. Urinary excretion data therefore were factored for kidney weight. Although hematocrit also increased with age, there was no change in hematocrit in any of the groups. Mean arterial blood pressure was greater in adult than young rats, and decreased with increasing doses of ANP infused (Fig. 1). In the five young rats that received an additional ANP dose of $1.6 \mu \mathrm{g} / \mathrm{kg} /$ min, MAP decreased further to $53.6 \pm 2.7 \mathrm{~mm} \mathrm{Hg}$.

Baseline plasma ANP concentration was twice as high in adult as in young rats (Table 1). An important and unexpected finding was a greater rate of increase in plasma ANP concentration with increasing doses in adult compared to young rats (Fig. 2; Table

Table 1. Body and kidney wt, hematocrit, plasma ANP concentration, and $U_{c G M P} V$ in rats of different ages (mean $\left.\pm S E\right)$

\begin{tabular}{|c|c|c|c|c|c|c|c|}
\hline & \multirow[t]{3}{*}{$n$} & \multirow{3}{*}{$\begin{array}{c}\text { Body wt } \\
\text { (g) }\end{array}$} & \multirow{3}{*}{$\begin{array}{c}\text { Left } \\
\text { kidney wt } \\
\text { (g) }\end{array}$} & \multicolumn{2}{|c|}{ Hematocrit (\%) } & \multirow{3}{*}{$\begin{array}{c}\text { Plasma } \\
\text { [ANP] } \\
(\mathrm{pg} / \mathrm{ml}) \\
\text { Pre } \\
\text { ANP infusion }\end{array}$} & \multirow{3}{*}{$\begin{array}{c}\mathrm{U}_{\mathrm{cGmp}} \mathrm{V} \\
\text { (pM/min/g } \\
\text { kidney wt) } \\
\text { Pre } \\
\text { ANP infusion }\end{array}$} \\
\hline & & & & Pre & End & & \\
\hline & & & & AN & sion & & \\
\hline \multirow[t]{2}{*}{ Adult } & 6 & 251.2 & 1.420 & 43.3 & 44.8 & 42.0 & 9.0 \\
\hline & & \pm 11.6 & \pm 0.088 & \pm 1.0 & \pm 0.6 & \pm 5.7 & \pm 2.5 \\
\hline \multirow[t]{2}{*}{$35-41$ days } & 5 & 102.0 & 0.677 & 38.0 & 41.0 & 21.7 & 11.6 \\
\hline & & $\pm 5.4^{*}$ & $\pm 0.075^{*}$ & $\pm 1.0^{*}$ & $\pm 0.7^{*}$ & $\pm 4.9^{*}$ & \pm 4.3 \\
\hline \multirow[t]{2}{*}{$31-32$ days } & 5 & 81.6 & 0.605 & 39.2 & 39.2 & 18.1 & 22.1 \\
\hline & & $\pm 4.0^{*}$ & $\pm 0.051^{*}$ & $\pm 0.5^{*}$ & $\pm 0.6^{*}$ & $\pm 5.1^{*}$ & $\pm 0.5^{*}, \uparrow$ \\
\hline
\end{tabular}

${ }^{*} p<0.05$ versus adult; $\uparrow p<0.05$ versus $35-41$ days. 


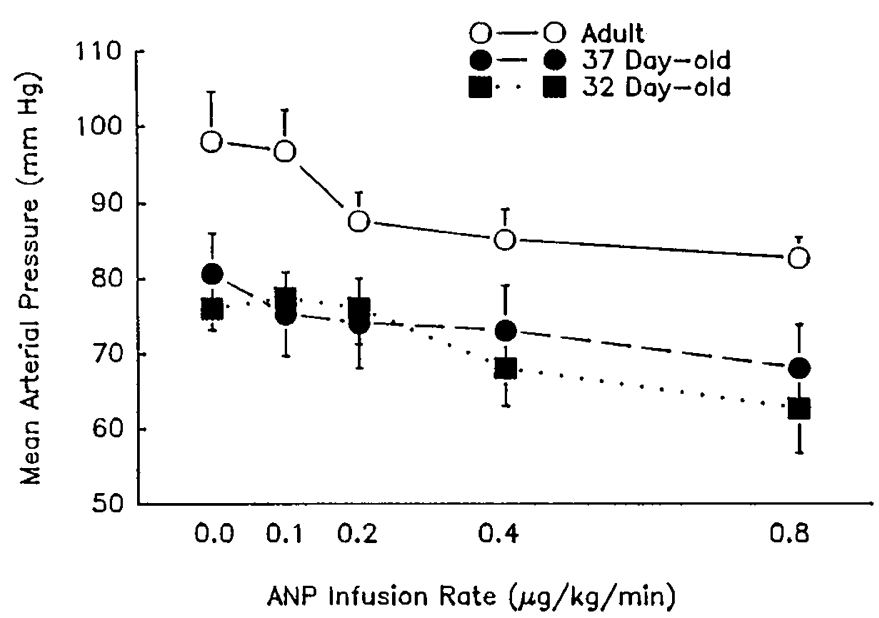

Fig. 1. Effect of ANP infusion on mean arterial pressure in rats of various ages. Each point represents mean $\pm \mathrm{SE}$ for each group.

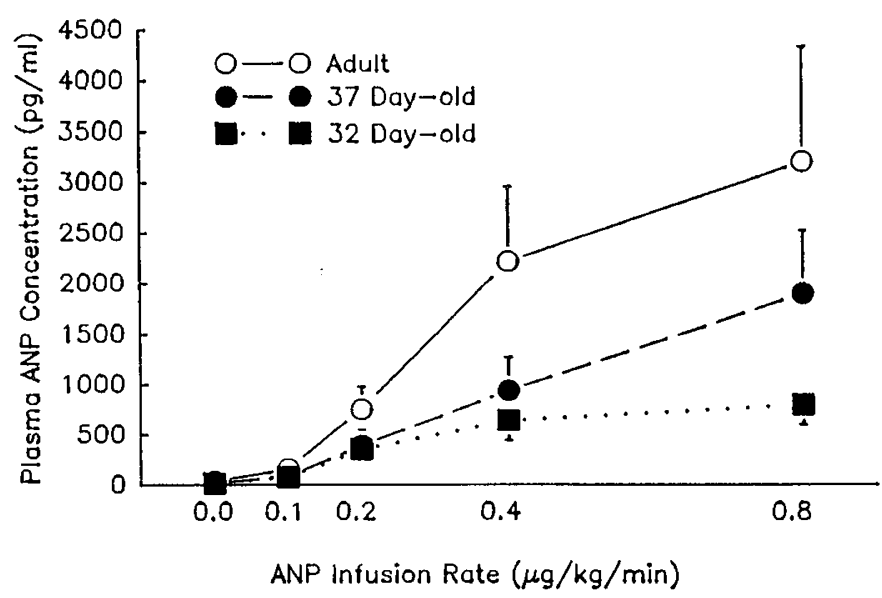

Fig. 2. Effect of ANP infusion on plasma ANP concentration in rats of various ages.

Table 2. Relationships between ANP infusion dose or plasma concentration and measured parameters as a function of age

\begin{tabular}{clccc}
\hline Figure & Parameter & $\begin{array}{c}\text { Adult versus } \\
\text { 35-41 days }\end{array}$ & $\begin{array}{c}\text { Adults versus } \\
31-32 \text { days }\end{array}$ & $\begin{array}{c}35-41 \text { versus } \\
31-32 \text { days }\end{array}$ \\
\hline \multicolumn{5}{c}{ Relationship to ANP dose (slope/intercept)* } \\
1 & Blood pressure & $\mathrm{NS} / 0.0001$ & $\mathrm{NS} / 0.0001$ & $\mathrm{NS} / \mathrm{NS}$ \\
2 & Plasma [ANP] & $0.04 / \mathrm{NS}$ & $0.009 / 0.02$ & $\mathrm{NS} / \mathrm{NS}$ \\
$3 A$ & Urine flow rate & $\mathrm{NS} / 0.02$ & $0.04 / 0.0002$ & $\mathrm{NS} / \mathrm{NS}$ \\
$3 B$ & $\mathrm{U}_{\mathrm{Na}} \mathrm{V}$ & $\mathrm{NS} / 0.03$ & $\mathrm{NS} / 0.02$ & $\mathrm{NS} / \mathrm{NS}$ \\
$3 C$ & $\mathrm{U}_{\mathrm{GGMP}}$ & $0.006 / 0.004$ & $0.001 / 0.007$ & $\mathrm{NS} / \mathrm{NS}$
\end{tabular}

Relationship to plasma ANP concentration (slope/intercept)*

$\begin{array}{lll}4 A & \text { Urine flow rate } & 0.04 / 0.0001 \\ 4 B & \mathrm{U}_{\mathrm{Na}} \mathrm{V} & \mathrm{NS} / 0.03 \\ 4 C & \mathrm{U}_{\mathrm{cGMP}} \mathrm{V} & \mathrm{NS} / \mathrm{NS}\end{array}$

${ }^{*} p$ values for comparisons of slopes/intercepts of regression lines in Figures. For Figures 1 to 3, regression is for ANP infusion rates of 0 to $0.4 \mu \mathrm{g} / \mathrm{kg} / \mathrm{min}$.

2). In the five young rats receiving an additional ANP infusion of $1.6 \mu \mathrm{g} / \mathrm{kg} / \mathrm{min}$, plasma ANP concentration was $1228 \pm 144$ $\mathrm{pg} / \mathrm{ml}$, which averaged $25 \%$ above levels obtained at $0.8 \mu \mathrm{g} / \mathrm{kg} /$ min in the same animals ( $p=\mathrm{NS})$.

As shown in Figure $3 A$, urine flow rate was higher in adult than young rats, and the rate of increase with increasing ANP dose was higher in adults compared to 32-day-old animals (Table 2). When urine flow was related to plasma ANP concentration (Fig. 4A), these differences persisted (Table 2): Although $\mathrm{U}_{\mathrm{Na}} \mathrm{V}$ was greater in adults than young rats, there was no difference in
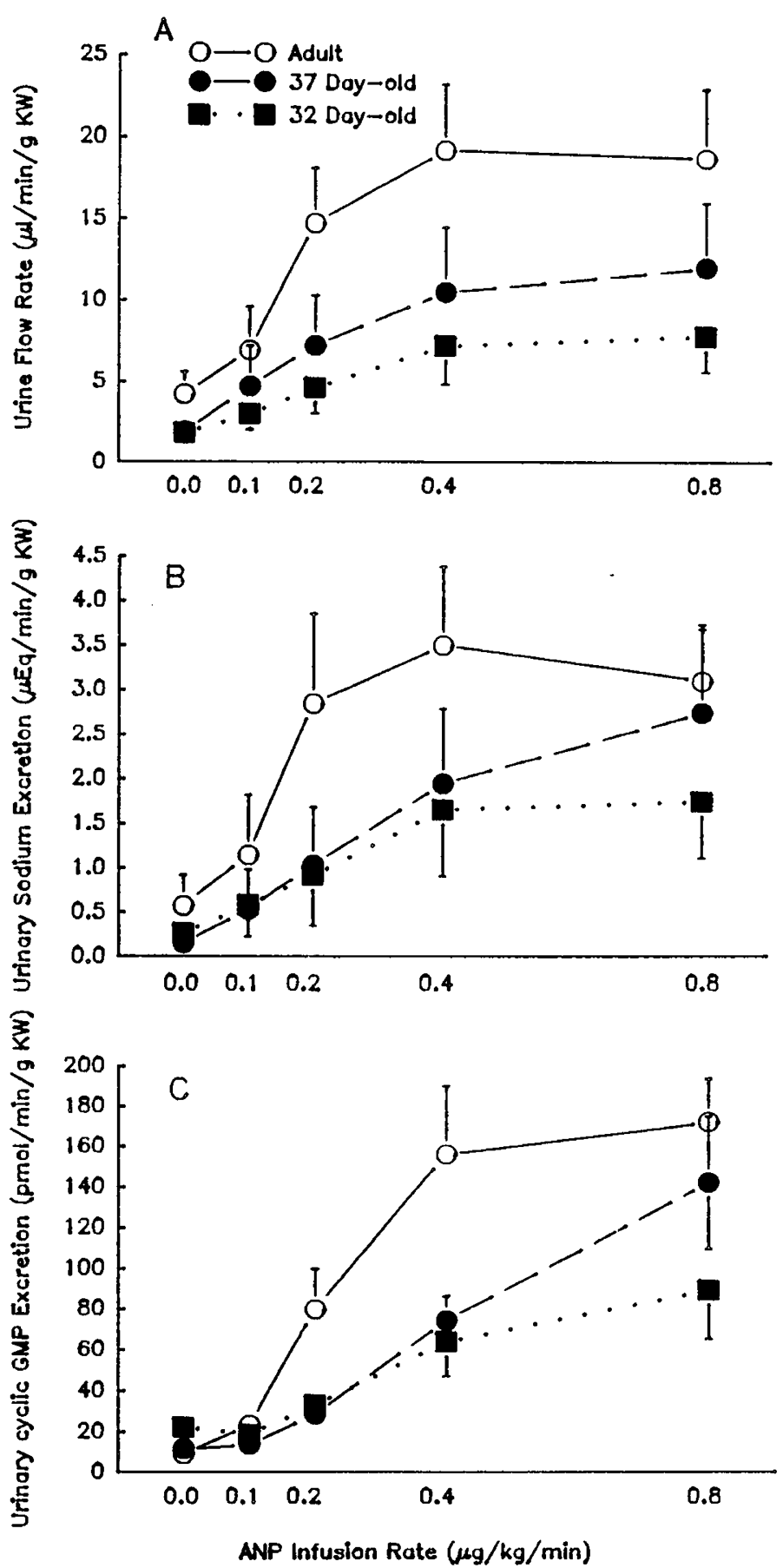

Fig. 3. Effects of ANP infusion on urinary parameters in rats of various ages. (KW, kidney weight). $A$. urine flow rate; $\mathrm{B}$. urinary sodium excretion; C. urinary cGMP excretion.

the rate of increase with increasing ANP infusion to $0.4 \mu \mathrm{g} / \mathrm{kg} /$ min (Figs. $3 B$ and $4 B$; Table 2).

As shown in Table 1 , baseline $U_{c G M P} V$ was greatest in the youngest rats. However, the rate of increase in $\mathrm{U}_{\mathrm{CGMP}} \mathrm{V}$ with increasing ANP infusions up to $0.4 \mu \mathrm{g} / \mathrm{kg} / \mathrm{min}$ was greater in adults than in young rats (Fig. $3 C$ ). This effect was due entirely to higher plasma ANP levels achieved during infusion of the peptide into adult animals, because the relationship of cGMP excretion to plasma ANP was virtually identical in adult and 32day-old rats (Fig. $4 C$ ).

There was no difference between 37- and 32-day-old rats in the relationships depicted in Figures 1-3. There was no additional increase in urine flow, $\mathrm{U}_{\mathrm{Na}} \mathrm{V}$, or $\mathrm{U}_{\mathrm{cGMP}} \mathrm{V}$ excretion during infusion of ANP at $1.6 \mu \mathrm{g} / \mathrm{kg} / \mathrm{min}$ in five young rats.

As shown in Figure 5, GFR increased by approximately $50 \%$ 

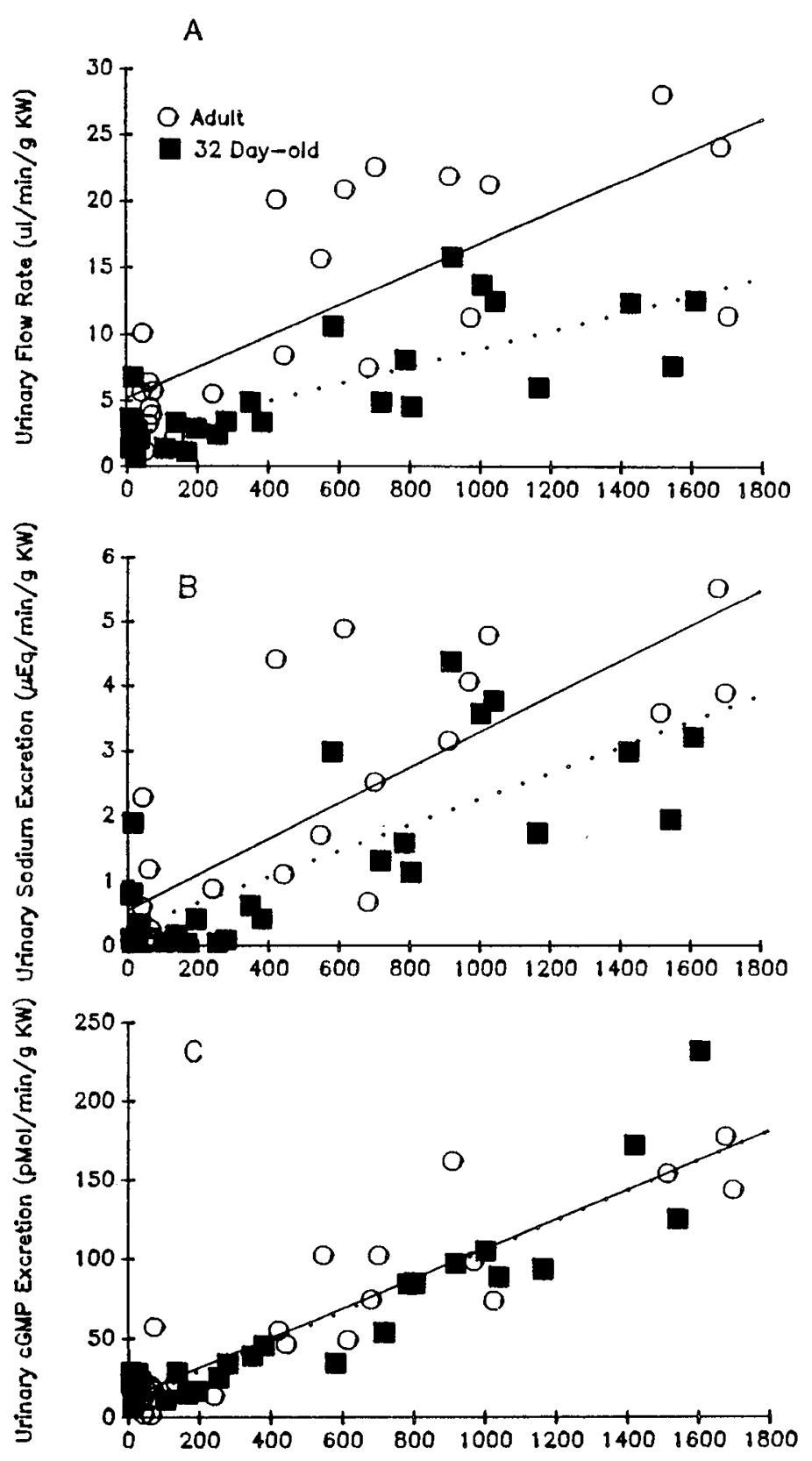

Plasmo ANP Concentration (pg/ml)

Fig. 4. Relationship between plasma ANP concentration and urinary parameters in rats of various ages. Each point depicts individual determinations. $A$. urinary flow rate (Adult $\mathrm{R}=0.75 ; 32$ day-old $\mathrm{R}=0.78$ ); B. urinary sodium excretion (Adult $\mathrm{R}=0.80 ; 32$ day-old $\mathrm{R}=0.76$ ); $\mathrm{C}$. urinary cGMP excretion (Adult $\mathrm{R}=0.92 ; 32$ day-old $\mathrm{R}=0.93$ ).

as a result of ANP infusion in adult rats, whereas there was no significant increase in young animals. There was no progressive increase in GFR with increasing dose of ANP in either group.

\section{DISCUSSION}

The major finding in the present study is that systemic clearance of ANP decreased with age of the rat. A variety of tissues is capable of clearing ANP, including kidney, liver, lung, and heart $(11,12)$. Although initial reports suggested that the plasma halflife of ANP was several minutes $(11,13)$, the half-life, actually may be less than $30 \mathrm{~s}$ in the adult rat (14). Braunlich and Solomon (15) found that infusion of atrial extract from adult rats caused a greater diuresis and fractional sodium excretion in older than

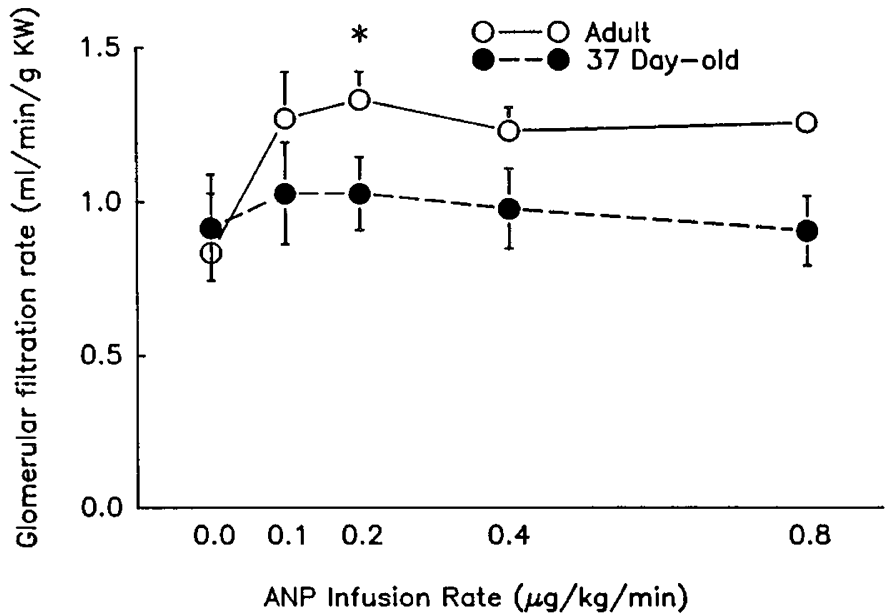

Fig. 5. Effects of ANP infusion on glomerular filtration rate in young and adult rats. ${ }^{*} \mathrm{p}<0.05$ vs. pre-ANP infusion, same group. Overall GFR for adult group was greater than that for young group $(p<0.02)$.

younger animals. Inasmuch as plasma levels of ANP were not measured, the results of the latter report are compatible with either increasing renal sensitivity to ANP or decreased clearance of ANP from the plasma of older animals, as was found in the present study.

Although peptide hydrolysis initially was postulated to be the primary mechanism for ANP clearance (14), most renal removal of ANP has been shown to be due to specific cortical binding rather than hydrolysis (16). An intriguing explanation of these findings relates to the discovery of multiple subpopulations of ANP receptors (17). The predominant (C-ANF) receptors present in smooth muscle (17) and kidney (18) avidly bind ANP but are not coupled to cGMP, unlike B-ANF receptors that mediate the known physiologic actions of ANP on target tissues. The biologically silent C-ANF receptors therefore may serve as storage or clearance binding sites. It is tempting to postulate that young rats have a greater proportion of C-ANF receptors that bind exogenous ANP, resulting in a lower plasma concentration. In the present study, the higher baseline plasma ANP concentration in adult rats therefore may relate to fewer C-ANF receptors. Because the response in $U_{\text {CGMP }} V$ to plasma ANP concentration was identical in young and adult rats, the relative density of BANF receptors presumably may not change with growth.

Since the original observation of Hamet et al. (19) that cGMP is generated in response to ANP, numerous studies have confirmed the activation of particulate guanylate cyclase by circulating ANP (8). In the present study, there was a strong correlation between $\mathrm{U}_{\mathrm{CGMP}} \mathrm{V}$ and plasma ANP concentration regardless of age. Whereas plasma or urinary cGMP levels may serve as a biologic marker for ANP activity, the source of cGMP cannot be determined from the present data.

Although MAP was greater in adult than young rats, an increase in the dose of ANP to $1.6 \mu \mathrm{g} / \mathrm{kg} / \mathrm{min}$ reduced MAP more in young animals than in adults despite lower ANP levels in younger animals. It would appear, therefore, that young rats are more sensitive to the hypotensive effects of ANP. Plasma levels of angiotensin II are elevated in young rats 30 to 40 days of age (20). Because ANP appears to exert greater vasorelaxant effects in the presence of vasoconstrictors (21), it is not surprising that high doses of ANP reduced MAP to a greater extent in young than in adult animals in the present study.

Throughout the ANP infusion, urine flow and sodium excretion of adult rats remained greater than those of young animals. Whereas increasing the dose of ANP infusion to $0.4 \mu \mathrm{g} / \mathrm{kg} / \mathrm{min}$ did not significantly alter this relationship for $\mathrm{U}_{\mathrm{Na}} \mathrm{V}$, the rise in urine flow was greater in adults even when related to plasma ANP concentration. This indicates an increasing renal diuretic response to ANP with growth. One possibility is that the increase 
in GFR due to ANP infusion in adult animals in the present study contributed to the greater diuretic response compared to young animals which showed no change in GFR with ANP infusion. In Munich-Wistar rats of weights similar to young animals in the present study, Roy (22) found that ANP infusion $(0.1 \mu \mathrm{g} / \mathrm{kg} / \mathrm{min})$ reduced GFR by $27 \%$, but there was no change in GFR in larger rats (22). These divergent results may be due to strain differences. Nevertheless, because urine flow increased with ANP infusion in young animals in both studies, there may be age-related changes in direct ANP-mediated inhibition of vasopressin action on the tubule (23).

In summary, we have shown that ANP infusion caused a dosedependent decrease in MAP in young and adult rats. Although the rise in GFR, urine flow rate, and $U_{C G M P} V$ were greater in adult than young rats, the rise in plasma ANP concentration was significantly greater in adults, indicating a decrease in systemic clearance of ANP with growth. When related to plasma ANP concentration, there was no difference in $U_{c G M P} V$ between young and adult rats, suggesting that the metabolic response to ANP did not change after 30 days of age in the rat. However, increasing levels of plasma ANP resulted in a greater rise in urine flow in adult than young rats, suggesting that the renal diuretic response to ANP increased with age, and may be at least partially independent of guanylate cyclase. Whereas young rats were found to excrete less urinary sodium than adults, the rate of increase in sodium excretion with increasing ANP dose was similar. We conclude that changing ANP pharmacokinetics with age may contribute to an increasing renal response to infusion of the peptide in adult compared to young animals.

Acknowledgment. The assistance of Dr. Donald Kaiser in statistical analysis is gratefully acknowledged.

\section{REFERENCES}

1. Spitzer A 1978 Renal physiology and functional development. In: Edelmann CM (ed) Pediatric Kidney Disease. Little, Brown, Boston, pp 25-128

2. Goldsmith DI, Drukker A, Blaufox MD, Edelmann, Jr. CM, Spitzer A 1979 Hemodynamic and excretory response of the neonatal canine kidney to acute volume expansion. Am J Physiol 237:F392-F397

3. Aperia A, Elinder G 1981 Distal tubular sodium reabsorption in the developing rat kidney. Am J Physiol 240:F487-F491
4. Bengele $\mathrm{HH}$, Solomon S 1974 Development of renal response to blood volume expansion in the rat. Am J Physiol 227:364-368

5. Solomon S, Hathaway S, Curb D 1979 Evidence that the renal response to volume expansion involves a blood-borne factor. Biol Neonate 35:113-120

6. deBold AJ, Borenstein HB, Veress AT, Sonnenberg $\mathrm{H} 1981$ A rapid and potent natriuretic response to intravenous injection of atrial myocardial extract in rats. Life Sci 28:89-94

7. Ballermann BJ, Brenner BM 1987 Atrial natriuretic peptide and the kidney. Am J Kidney Dis 10:7-12

8. Gerzer R, Heim J-M, Schutte B, Weil J 1987 Cellular mechanisms of action of atrial natriuretic factor. Klin Wochenschr 65:109-114

9. Brooker G, Terasaki WL, Price MG 1976 Gammaflo: a completely automated radioimmunoassay system. Science 194:270-276

10. Patel A, Linden J 1988 Purification of ${ }^{125}$ I-labelled succinyl cyclic nucleotide tyrosine methyl esters by high-performance liquid chromatography. Anal Chem 168:417-420.

11. Tang J, Webber RJ, Chang D, Chang JK, Kiang J, Wei ET 1984 Depressor and natriuretic activities of everal atrial peptides. Regul Pept 9:53-59

12. Crozier IG, Nicholls G, Ikram H, Espiner EA, Yandle TG, Jans S 1986 Atria natriuretic peptide in humans. Production and clearance by various tissues. Hypertension 8:II-11-II-15

13. Ledsome JR, Wilson N, Rankin AJ, Courneya CA 1985 Time course of release of atrial natriuretic peptide in the anaesthetized dog. Can J Physiol Pharmacol 64:1017-1022

14. Luft FC Lang RE Aronoff GR, Ruskoaho $H$ Toth $M$, Ganten D, Sterzel B Unger $T 1985$ Atriopeptin III kinetics and pharmacodynamics in normal and anephric rats. J Pharmacol Exp Ther 236:416-418

15. Braunlich H, Solomon S 1987 Renal effects of atrial natriuretic factor in the rats of different ages. Physiol Bohemoslovaca 36:119-124

16. Suzuki M, Almeida FA, Nussenzveig DR, Sawyer D, Maack T 1987 Binding and functional effects of atrial natriuretic factor in isolated rat kidney. Am J Physiol 253:F917-F928

17. Scarborough RM, Schenk DB, McEnroe GA, Arfsten A, Kang L-L, Schwart K, Lewicki JA 1986 Truncated atrial natriuretic peptide analogs. J Biol Chem 261:12960-12964

18. Maack T, Suzuki M, Almeida FA, Nussenzveig D, Scarborough RM, McEnroe GA, Lewicki JA 1987 Physiological role of silent receptors of atrial natriuretic factor. Science 238:675-678

19. Hamet P, Tremblay J, Pang SC, Garcia R, Thibault G, Gutkowska J, Cantin M, Genest J 1984 Effect of native and synthetic atrial natriuretic factor on cyclic GMP. Biochem Biophys Res Commun 123:515-527

20. Wallace KB, Hook JB, Bailie MD 1980 Postnatal development of the reninangiotension system in rats. Am J Physiol 238:R432-R437

21. Proctor KG, Bealer SL 1987 Selective antagonism of hormone-induced vasoconstriction by synthetic atrial natriuretic factor in the rat microcirulation. Circ Res 61:42-49

22. Roy DR 1986 Effect of synthetic ANP on renal and loop of Henle functions in the young rat. Am J Physiol 251:F220-F225

23. Dillingham MA, Anderson RJ 1986 Inhibition of vasopressin action by atrial natriuretic factor. Science 231:1572-1573 